\title{
Students Unrest in Higher Education Level in Bangladesh a Study on Dhaka and Rajshahi University
}

\author{
Dr. Md. Khaleduzzaman \\ Associate Professor Institute of Education \& Research University of Rajshahi, Bangladesh
}

\begin{abstract}
The study mainly dealt with the causes and effects of students' unrest on higher education level in Bangladesh. The study has tried to explore the various causes of student unrest in higher education level institutions and at the same time has shown the various effects of it on society and individual. There are some duties to be performed of the govt., university authority, guardians and students equally. As a result of student unrest family of the guardians keep them always in anxiety, frustration and other mental troubles. They do not know whether their sons/daughters will complete their education or not or whether their sons/daughters will live up to the completion of their learning. So, student unrest always keeps the guardians in mental anxiety. Society also suffers for student unrest. The impact of student unrest affects the whole society by giving the negative out look to the people. In some cases it has been found that they have a negative attitude towards higher education.
\end{abstract}

\section{Introduction}

Education is the process by which our mind develop through formal learning at an institution like a schools colleges or universities. ${ }^{1}$ Education helps man to understand what is right and what is wrong. An educated man is an asset but an uneducated man is a liability to the society. ${ }^{2}$ In Bangladesh, education is classified into four categories like; primary, secondary, higher secondary and higher level of education. So the study will focus the causes of students' unrest and its remedy so that the target of higher education can be achieved. Student unrest is the buzzword almost every educational institutions of the world. In the social change, the role of students has occupied a significant place. Students do not have any own interest in national affairs compared to other people of the society. So, they play an important role in various developmental issues of the country. History proves that student's unrest is mostly related to political clash of our national leaders. ${ }^{3}$ Moreover, university is the highest pick of the higher education. Here students can enlighten themselves studying according to the role of university. But it is unfortunately true that most of our educational institutions are corrupted by political influences. ${ }^{4}$ From which student's unrest is creating and students are involving themselves instead of studying. That is why higher education is threatened and sometimes the target of higher education cannot be achieved as to the expectation. The practical situation shows that universities are failure to do their duties to make our students highly educated thoroughly. In 1990, students took Part to the revolution to protest the oppressor Ershad and successfully defeated him. ${ }^{5}$ Some event of students unrest after liberation war were found that killing of Niha Banu, the resident student of Monnujan Hall of Rajshahi University and the killing of student leader Maznu are remarkable. At last the greatest student unrest was flashed after the killing of Professor S. Taher department of Zoology and Mining, University of Rajshahi in 2006 (The Daily Janakontho, 04.02.2006). Besides, these events, there are some other causes of students unrest which will be explored by this study. The researcher is very much interested to find out the nature and type of the students unrest in Bangladesh context and at the same time the researcher is intended to make relevant recommendation so that students' unrest may be controlled in the higher education level in Bangladesh.

\section{Statement of the Problem}

Student unrest is a common phenomenon in Bangladesh. It is needless to explain that it is a problem in higher education level. In the hypotheses the researcher tried to explain it in brief so that the assumption of the researcher may depict the picture of the problem and at the same time it may give a clear concept of the research work. Student Unrest affects the total higher education in Bangladesh. So, the impact of it may not give any positive outcome to the nation. The study has focused on two renowned Universities of the country and the type of the students Unrest and its effect on education. The research has also undertaken against the backdrop of irregular outburst of violent activities among the university students up to the time of writing. While the incidence of violence and indiscipline could be seen as symptomatic of a deeper malaise within the larger social system as well as within the university system as a whole, they have been occasioned by a variety of deficiencies in the administrative, academic, and managerial aspects of the university systems. The lacunae in university administration and teaching have given occasion for entry of forces and organizations outside the university to encroach on and usurp duties that should properly fall within the purview of university administrations and thereby serve as opportunities for such external forces to recruit new members, mobilize 
students for protests and demonstrations, and use them as instruments for enlarging the party revenues and activities. Since violence and indiscipline in the universities have multiple causes. They require multidimensional solutions that will need re-thinking on such critical areas as methods of conflict resolution, introducing courses that have a practical orientation especially for arts degree students, providing more opportunities for women participation in student councils, counseling services at intra-departmental level, demanding accountability and transparency in affairs of student bodies, seeking viable alternatives to the policy of having residential campuses, introducing minimum levy meaningful participation of students in the management of universities. The study also suggested that far reaching and multi sector changes are set in place, the universities will always continue to be hotbeds of political agitation, activism and violence given the fact that there will always be shortfalls in government funding that will lead to reduced quality of services and facilities available at all universities. In such context, the epicenters of student unrest and violence need not be confined to the big campuses. But the fledging universities that have been created in the peripheral areas since the latter enjoy even less resources when compared to the already established institutions of higher education. With regard to policy changes, the study recommends among other thing, granting of greater autonomy to universities and reductions of government's role to providing of funds, giving priority to numbers of students in universities as a criteria for disbursement of funds, changing the funds, changing the present district quota system when admitting students to universities, changing levy for higher education, increasing levies for hostel accommodation and facilities, de-emphasize the present system of having residential campus and improve facilities for distance education, introduce in applied orientation in academic teaching programs, change school syllabi to promote character-building, social awareness and practical skills among students, and improve capacity of universities t5o handle violence and indiscipline. So, students' unrest is a problem in the higher education levels. So, this field may be an important issue of conducting research and at the same time after completion of the research, it may be easy to find out remedy of students' unrest.

\section{Key concepts}

Some key concepts which should be clear to understand the inner meaning of the research are given in below:

\section{Impact}

Impact always refers to the total result of any events. ${ }^{6}$ In this study, impact refers to the total effect or consequences of student's unrest of our higher education.

\section{Student}

A student is a learner who is enrolled in an educational institution. A university student is he or she who is studying a particular field as the principal subject. In this study, students refer to University students, M. Phil. and Ph. D. Students.

\section{Unrest}

The phrase student unrest usually refers to demonstrations, the occupation of campus buildings and even some minor riots by students in the period from about 1967 till the early 1970s. ${ }^{7}$ It affected most of Western Europe and the U.S. Nearly all the students involved were opposed to the role of the U.S. in the Vietnam War. Beyond that, student grievances tended to vary from country to country. Student unrest was most prolonged and violent in West Germany. There the students were not only protesting against overcrowding in the universities but what they say as the failure of their parents to confront Nazism properly. In this study, unrest refers to the unexpected situation in the educational institutions for which educational development cannot be achieved fruitfully.

\section{Student Unrest}

Every responsible person today complains of the growing indiscipline among student. This is a fact borne out by daily happenings. Students go on strike whenever something is done against their will. They insult their teachers. In examinations, they insist on coping. If any invigilator checks them, he is threatened. All clearly proves that our students are indiscipline. In this study student unrest generally means the unexpected behavior of the students and students' indiscipline created by some problems of educational institutions. It is as to the students' violence in the campus; strike i.e. unexpected closers of the institutions, clash of rival groups, violation of examination, shattering, plundering etc. 


\section{Higher Education}

Higher education refers to a level of education that is provided at and certain other collegiate-level institutions, such as vocational schools, trade schools, and career colleges, that award academic degrees or professional certifications. In this study, the researcher meant the university level education as higher education i.e. the level of graduation, honors, M. Phil and Ph. D.

\section{Objectives of the Study}

- To know the causes and effects of students' unrest in higher education

-To recommend how to remove students' unrest and how to prevent it from higher education

\section{Research Methodology}

The nature of the study refers to the social survey and is related to social phenomenon. Case Study, Participant Observation and Focus Group Discussion (FGD) were followed in his study. Dhaka and Rajshahi Universities, the highest educational institutions of Bangladesh have been selected as the study field for this research. Data were collected from the primary and secondary sources of materials. For primary source, the data were collected through structured questionnaire relating to the impact of students' unrest from Rajshahi and Dhaka University. The questionnaire was divided into two sets. One set is regarding teachers' and another is regarding teachers' information of the study area. To know the type and nature of the students' unrest of Rajshahi and Dhaka Universities, selected respondents (201 students and 27 teachers from Dhaka University and 141 students and 15 teachers from Rajshahi University) from both of the institutions were interviewed. Considering the nature of the study some closely related parameters have been looked in to account. The collected data have been processed and presented below in convenient ways.

\section{Findings of the Study}

\section{Residence of the Respondents}

Especially the residential student faces many difficulties compared to the non-residential student in the university level. ${ }^{8}$ They face the problems in their own eyes and sense. So, they can supply reliable data. For this reason, respondent have been distributed residential and non-residential so that the study may present the expected result.

Table: Percentage Distribution of the Respondents by Their Residence

\begin{tabular}{|c|c|c|c|c|c|c|}
\hline \multirow{2}{*}{$\begin{array}{ll}\text { Type } & \text { of } \\
\text { Resident } & \end{array}$} & \multicolumn{2}{|c|}{ Dhaka University } & \multicolumn{2}{|c|}{ Rajshahi University } & \multicolumn{2}{|l|}{ Total } \\
\hline & $\begin{array}{l}\text { No. of } \\
\text { Respondents }\end{array}$ & $\begin{array}{l}\text { Percentage } \\
\%\end{array}$ & $\begin{array}{l}\text { No. of } \\
\text { Respondents }\end{array}$ & $\begin{array}{l}\text { Percentage } \\
\%\end{array}$ & Respondents & $\begin{array}{l}\text { Percentage } \\
\%\end{array}$ \\
\hline Hall & 85 & 37.29 & 95 & 60.89 & 180 & 46.875 \\
\hline Mess & 68 & 29.82 & 40 & 25.65 & 108 & 28.125 \\
\hline House & 65 & 28.50 & 17 & 10.89 & 82 & 21.354 \\
\hline Others & 10 & 04.39 & 04 & 02.57 & 14 & 03.645 \\
\hline Total & 228 & 100 & 156 & 100 & 384 & 100 \\
\hline
\end{tabular}

The table shows that $37.29 \%$ students of Dhaka University residing in the hall as against $60.89 \%$ students of Rajshahi University respectively. It is also found that average $46.875 \%$ students are residing in both of the Universities under the study. Other includes relatives and guests houses.

\section{Concept about Students' Unrest in Higher Education}

The researcher has tried to study the general knowledge on students' Unrest of the respondents. Students were asked 'yes' 'no' questions whether they have idea or not about the concept of students unrest. The picture of the data has been given in the following table.

\section{Comments on How Student Unrest Outbreak in Higher Education}

The type of outburst of the students' unrest in both of the universities has been shown in the following table. 
Table: Percentage Distribution of the Respondents by Their Comments on How Student Unrest Outbreak in Higher Education

\begin{tabular}{|c|c|c|c|c|c|c|}
\hline \multirow{2}{*}{$\begin{array}{l}\text { Type of out } \\
\text { burst } \\
\text { students' unrest }\end{array}$} & \multicolumn{2}{|l|}{ Dhaka University } & \multicolumn{2}{|c|}{ Rajshahi University } & \multicolumn{2}{|l|}{ Total } \\
\hline & $\begin{array}{l}\text { No. of } \\
\text { Respondents }\end{array}$ & $\begin{array}{l}\text { Percentage } \\
\%\end{array}$ & $\begin{array}{l}\text { No. of } \\
\text { Respondents }\end{array}$ & $\begin{array}{l}\text { Percentage } \\
\%\end{array}$ & Respondents & $\begin{array}{l}\text { Percentage } \\
\%\end{array}$ \\
\hline $\begin{array}{l}\text { Fortuitous } \\
\text { Hortal }\end{array}$ & 150 & 65.79 & 110 & 70.52 & 260 & 67.708 \\
\hline $\begin{array}{l}\text { Breaking and } \\
\text { Firing }\end{array}$ & 20 & 08.78 & 12 & 07.69 & 32 & 08.333 \\
\hline $\begin{array}{l}\text { Confining of } \\
\text { office }\end{array}$ & 25 & 10.96 & 15 & 09.62 & 40 & 10.416 \\
\hline $\begin{array}{l}\text { Killing and } \\
\text { biting }\end{array}$ & 20 & 08.77 & 14 & 08.97 & 34 & 08.854 \\
\hline Others & 13 & 05.70 & 05 & 03.20 & 18 & 04.687 \\
\hline Total & 228 & 100 & 156 & 100 & 384 & 100 \\
\hline
\end{tabular}

The table shows that $65.78 \%$ students of Dhaka and $70.52 \%$ students of Rajshahi University consider the Fortuitous Hortal is the main issues of occurring students' unrest in the Universities in our country. Average $67.708 \%$ students of both of the universities consider the main issues of occurring students' unrest in the Universities in our country.

\section{The Main Causes of Students' Unrest in Higher Education of Bangladesh}

There are many causes of students' unrest in the university level. The researcher has tried to find out the prime causes of students' unrest. Not that the some other causes have been less cared. Causes are identified prime and less important because to make recommendation and suggestion, it would be easy for the researcher. Moreover, some unseen causes of students' unrest which have been laid in the administrative activities are not come to the students easily. So, it would be better for the study to find out the prime causes of students' unrest so that students can give their answer easily of the questionnaire required.

Table: Percentage Distribution of the Respondents by Their Comments on the Main Causes of Student Unrest in Higher Education of Bangladesh

\begin{tabular}{|l|l|l|l|l|l|l|}
\hline \multirow{2}{*}{ Type of causes } & \multicolumn{2}{|l|}{ Dhaka University } & \multicolumn{2}{l|}{ Rajshahi University } & Total \\
\cline { 2 - 7 } & $\begin{array}{l}\text { No. of } \\
\text { Respondents }\end{array}$ & $\begin{array}{l}\text { Percentage } \\
\%\end{array}$ & $\begin{array}{l}\text { No. of } \\
\text { Respondents }\end{array}$ & $\begin{array}{l}\text { Percentage } \\
\%\end{array}$ & Respondents & $\begin{array}{l}\text { Percentage } \\
\%\end{array}$ \\
\hline Session Jam & 55 & 24.13 & 35 & 22.44 & 90 & 23.437 \\
\hline Students Politics & 118 & 51.76 & 85 & 54.48 & 203 & 52.864 \\
\hline Teachers Politics & 30 & 13.16 & 18 & 11.54 & 48 & 12.05 \\
\hline $\begin{array}{l}\text { Residential } \\
\text { Problem }\end{array}$ & 10 & 04.38 & 10 & 06.41 & 20 & 05.208 \\
\hline Other Problems & 15 & 06.57 & 08 & 05.13 & 23 & 05.989 \\
\hline Total & 228 & 100 & 156 & 100 & 384 & 100 \\
\hline
\end{tabular}

The table shows that $51.76 \%$ students of Dhaka University have commented as the prime cause of students Unrest is student politics as against $54.48 \%$ students of Rajshahi University respectively. Average $52.864 \%$ students both of the Universities considered the student politics as the prime cause of students' unrest under the study.

\section{Opinion of the Respondents about Departmental Session Jam}

For the negligence and some limitations of the university authorities, they cannot take yearly examinations in time. ${ }^{9}$ It is now a day a common scene in almost of the universities. For this reason, students have to suffer for session jam. They drop their valuable time in life. Comments of the respondents on session jam in general of the university have been given in the following table.

Table: Departmental Session Jam

\begin{tabular}{|l|l|l|l|l|l|l|}
\hline \multirow{2}{*}{$\begin{array}{l}\text { Type of } \\
\text { Question }\end{array}$} & Dhaka University & Rajshahi University & Total \\
\cline { 2 - 7 } & No. of Respondents & $\begin{array}{l}\text { Percentage } \\
\%\end{array}$ & $\begin{array}{l}\text { No. of } \\
\text { Respondents }\end{array}$ & $\begin{array}{l}\text { Percentage } \\
\%\end{array}$ & No. of Respondents & $\begin{array}{l}\text { Percentage } \\
\%\end{array}$ \\
\hline Yes & 30 & 13.15 & 18 & 11.53 & 48 & 12.5 \\
\hline No & 198 & 86.85 & 138 & 88.47 & 336 & 87.5 \\
\hline Total & 228 & 100 & 156 & 100 & 384 & 100 \\
\hline
\end{tabular}


The table shows that $13.15 \%$ respondents of Dhaka University and $11.53 \%$ respondents of Rajshahi University given their answers 'Yes' in the context of responsibility of session jam to create students' unrest. Average $12.5 \%$ respondents have given 'Yes' answers against session jam in creating students' unrest. The following table has focused the conditions of both the university under the study.

\section{Opinion of the Respondents about Transportation}

Sometimes students have to face extreme problem for bus transportation. University cannot provide the students required transport facility. ${ }^{10}$ They get on the bus huddled situation which creates unrest among the students. It rises for inadequate buses. So, the researcher has looked the transportation problem into account for the study. The following table has paid attention about the opinion of the respondents regarding transport facility.

Table: Percentage Distribution of the Respondents by Their Opinion about Transport Facilities

\begin{tabular}{|l|l|l|l|l|l|l|}
\hline \multirow{2}{*}{$\begin{array}{l}\text { Type of Problems of } \\
\text { transport }\end{array}$} & \multicolumn{2}{|l|}{ Rhaja University } & \multicolumn{2}{l|}{ Total } \\
\cline { 2 - 7 } & $\begin{array}{l}\text { No. } \\
\text { Respondents }\end{array}$ & $\begin{array}{l}\text { Percentage } \\
\%\end{array}$ & $\begin{array}{l}\text { No. } \\
\text { Respondents }\end{array}$ & $\begin{array}{l}\text { Percentage } \\
\%\end{array}$ & Respondents & $\begin{array}{l}\text { Percentage } \\
\%\end{array}$ \\
\hline Inadequate Buses & 150 & 65.78 & 110 & 70.52 & 260 & 67.708 \\
\hline $\begin{array}{l}\text { The use of buses by } \\
\text { other non-students } \\
\text { and unknown persons }\end{array}$ & 50 & 21.92 & 25 & 16.03 & 75 & 19.531 \\
\hline $\begin{array}{l}\text { The whimsicalness of } \\
\text { the Bus laborer }\end{array}$ & 25 & 10.96 & 16 & 10.25 & 41 & 10.677 \\
\hline Others & 03 & 01.31 & 05 & 03.20 & 08 & 02.083 \\
\hline Total & 228 & 100 & 156 & 100 & 384 & 100 \\
\hline
\end{tabular}

65.78\% respondents of Dhaka University answered that the transport facility was inadequate as against $70.52 \%$ respondents of Rajshahi University respectively. Average $67.708 \%$ respondents told the same problem. So, the data proves that transport problem in both of the Universities are acutely existing.

\section{Opinion of the Respondent about Problem of Central Library}

Library is a store house of knowledge and it is the part and parcel of any educational institution. ${ }^{11}$ University education may not imagine without a large or huge library facilities. Students cannot manage all necessary books of higher education. So, they have to depend on library. Both Dhaka and Rajshahi universities having luxurious library, those have no sufficient books as to the requirement. ${ }^{12}$ Moreover, for dilapidated management system of distributing books exists both in the universities. So, many students are deprived have library facilities. Sometime it is observed that those universities are using for gossiping instead of reading books.

The type of problems of central library stated by the respondents has been given in the following table.

Table: Percentage Distributions of the Respondents on Faced Problems about Central Library

\begin{tabular}{|l|l|l|l|l|l|l|}
\hline \multirow{2}{*}{ Type of problem } & \multicolumn{2}{|l|}{ Dhaka University } & \multicolumn{2}{l|}{ Rajshahi University } & \multicolumn{2}{l|}{ Total } \\
\cline { 2 - 7 } & $\begin{array}{l}\text { No. of } \\
\text { Respondents }\end{array}$ & $\begin{array}{l}\text { Percentage } \\
\%\end{array}$ & $\begin{array}{l}\text { No. of } \\
\text { Respondents }\end{array}$ & $\begin{array}{l}\text { Percentage } \\
\%\end{array}$ & Respondents & $\begin{array}{l}\text { Percentage } \\
\%\end{array}$ \\
\hline $\begin{array}{l}\text { Lack of sufficient } \\
\text { necessary books }\end{array}$ & 75 & 32.89 & 62 & 39.74 & 137 & 35.677 \\
\hline $\begin{array}{l}\text { Lack of conducive } \\
\text { reading } \\
\text { environment }\end{array}$ & 65 & 28.51 & 52 & 33.37 & 117 & 30.648 \\
\hline $\begin{array}{l}\text { No books having } \\
\text { catalogue }\end{array}$ & 33 & 14.48 & 20 & 12.82 & 53 & 13.802 \\
\hline $\begin{array}{l}\text { Infrastructural } \\
\text { problem }\end{array}$ & 50 & 21.93 & 20 & 12.82 & 70 & 18.229 \\
\hline Others & 05 & 02.19 & 02 & 01.28 & 07 & 01.822 \\
\hline Total & 228 & 100 & 156 & 100 & 384 & 100 \\
\hline
\end{tabular}

The table shows that $32.89 \%$ respondents of Dhaka University and $39.74 \%$ respondents of Rajshahi University considered the lack of sufficient necessary books is responsible in the central library as the main problem. Average 35.677 students told the same problem. Though there are some catalogues in both of the universities, there is no book according to the list maintained in those catalogues. There also existing lack of favorable reading environment, Infrastructural problem and other problems too. 


\section{Opinion of the Respondents about Getting Seats}

Students have to face series of problems existed in years. The main causes of getting seats in the halls have been elicited from the victimized student of both of the universities. ${ }^{13}$ The causes which selected students observed of getting seats in the halls are given in the following tables.

Table: Percentage Distribution of the Respondents by Their Opinion on Getting Seats in the Halls

\begin{tabular}{|l|l|l|l|l|l|l|}
\hline \multirow{2}{*}{$\begin{array}{l}\text { Type of Problems } \\
\text { of Getting seats }\end{array}$} & \multicolumn{2}{l|}{ Dhaka University } & \multicolumn{2}{l|}{ Rajshahi University } & \multicolumn{2}{l|}{ Total } \\
\cline { 2 - 7 } & $\begin{array}{l}\text { No. of } \\
\text { Respondents }\end{array}$ & $\begin{array}{l}\text { Percentage } \\
\%\end{array}$ & $\begin{array}{l}\text { No. } \\
\text { Respondents }\end{array}$ & $\begin{array}{l}\text { Percentage } \\
\%\end{array}$ & \multicolumn{2}{l|}{ Respondents } \\
$\%$
\end{tabular}

The table shows that $54.39 \%$ respondents of Dhaka University and $54.49 \%$ respondents of Rajshahi University have incriminated inadequate seats is the main cause of problem of getting seats in the hall. Average $54.427 \%$ respondents told the same problem.

\section{Type of Meals in Dining of the Hall}

In every University hall, there is a meal system providing by the dining system. The dining handlers are not associated with the university activities. ${ }^{14}$ They are quite out comer. So, they always try to extort money from the students supplying less standard foods. As a result, sometimes student unrest breaks out. The standard of food has been given in the following table.

Table: Percentage Distribution of the Respondents on the Standard of Food in the Dining of Halls

\begin{tabular}{|c|c|c|c|c|c|c|}
\hline \multirow{2}{*}{$\begin{array}{l}\text { Standard } \\
\text { of Food }\end{array}$} & \multicolumn{2}{|l|}{ Dhaka University } & \multicolumn{2}{|l|}{ Rajshahi University } & \multicolumn{2}{|l|}{ Total } \\
\hline & $\begin{array}{ll}\text { No. } & \text { of } \\
\text { Respondent }\end{array}$ & Percentage & $\begin{array}{ll}\text { No. } & \text { of } \\
\text { Respondent }\end{array}$ & Percentage & Respondent & Percentage \\
\hline Very good & 00 & $00 \%$ & 00 & $00 \%$ & 00 & $00 \%$ \\
\hline Good & 00 & $00 \%$ & 00 & $00 \%$ & 00 & $00 \%$ \\
\hline $\begin{array}{l}\text { Low } \\
\text { quality }\end{array}$ & 85 & $100 \%$ & 95 & $100 \%$ & 180 & $100 \%$ \\
\hline Total & 85 & 100 & 95 & 100 & 180 & 100 \\
\hline
\end{tabular}

The table shows that $100 \%$ respondents of Dhaka University and $100 \%$ respondents of Rajshahi University stated that the standard of food is low quality in the halls. So, it causes the students' unrest in the university.

\section{Opinion of the Respondents about Cultural Activities}

Culture is that what we are and what we have. ${ }^{15}$ We have our culture which leads our whole life and generations. But for the cultural legislation, our generation has gone to pit. The foreign channels i.e. other destructive channels show the unexpected movies and fanatic activities which perishes our generations. They sometimes train themselves those activities. Now our culture is mixed with foreign corrupted culture and there is no any action against such activities. For the cultural legislation, Students cannot enjoy their life in balance. They cannot enjoy sane culture not only in university but also in every sphere of life. The type of the limitations of cultural activities has been given in the following table. 
Table: Percentage Distributions of the Respondents by Their Opinion on Limitations of Cultural Activities

\begin{tabular}{|l|l|l|l|l|l|l|}
\hline Type of problem & \multicolumn{2}{|l|}{ Dhaka University } & \multicolumn{2}{l|}{ Rajshahi University } & \multicolumn{2}{l|}{ Total } \\
\cline { 2 - 7 } & $\begin{array}{l}\text { No. of } \\
\text { Respondent }\end{array}$ & Percentage & $\begin{array}{l}\text { No. of } \\
\text { Respondent }\end{array}$ & Percentage & Respondent & Percentage \\
\hline $\begin{array}{l}\text { Lack of sane } \\
\text { cultural } \\
\text { organization }\end{array}$ & 120 & 52.64 & 90 & 57.69 & 210 & 54.687 \\
\hline $\begin{array}{l}\text { Practice of } \\
\text { politics in lieu of } \\
\text { culture }\end{array}$ & 30 & 13.16 & 22 & 14.10 & 52 & 13.54 \\
$\begin{array}{l}\text { Lack of } \\
\text { administrative } \\
\text { interest }\end{array}$ & 26 & 11.40 & 14 & 08.98 & 40 & 10.416 \\
\hline $\begin{array}{l}\text { Limitation of } \\
\text { cultural } \\
\text { auditorium }\end{array}$ & 42 & 18.42 & 25 & 16.02 & 67 & 17.447 \\
\hline Others & 10 & 04.38 & 05 & 03.21 & 15 & 03.906 \\
\hline Total & 228 & 100 & 156 & 100 & 384 & 100 \\
\hline
\end{tabular}

The table shows that there no favorable cultural environment in both of the universities. There students practice politics instead of cultural activities in most cases. There is no leading cultural organization who can lead learners to practice their own culture. Moreover, there is a lack of auditorium in both of the universities. All cultural activities are held in one auditorium. It may not be expected. 52.64\% respondents of Dhaka University and $57.69 \%$ respondents of Rajshahi University have incriminated the lack of sane cultural organization is a great problem in cultural area. Average 54.687\% students told the same answer. Moreover, there are some other limitations like, sane cultural organization, practice of politics in lieu of culture, lack of administrative interest and limitation of cultural auditorium under the study.

\section{Opinions of the Teachers on the Causes and Effects of Students' Unrest}

Teachers are the architect of a nation. They are also philosopher. ${ }^{16}$ They can change the society by their teaching. So, the researcher has looked teachers into account to explore the real causes so that it may be easy to give recommendation to remove students' unrest from the universities. The study has 20 teachers of Dhaka University and 16 teachers of Rajshahi University as the samples. They were also interviewed to understand the theme of the research questions. The thoughts of the teachers have been given in various aspects. Their thoughts about the causes and effects of students' unrest have also been viewed. These are given below. The following table shows the percentage distribution of the teachers on the causes of students' unrest.

Table: Percentage Distributions of the Respondents on the Causes of Students' Unrest in Higher Education Level

\begin{tabular}{|c|c|c|c|c|c|c|}
\hline \multirow{2}{*}{$\begin{array}{l}\text { Type } \\
\text { causes }\end{array}$} & \multicolumn{2}{|c|}{ Dhaka University } & \multicolumn{2}{|c|}{ Rajshahi University } & \multicolumn{2}{|l|}{ Total } \\
\hline & $\begin{array}{l}\text { No. of } \\
\text { Respondent }\end{array}$ & Percentage & $\begin{array}{l}\text { No. of } \\
\text { Respondent }\end{array}$ & Percentage & Respondent & Percentage \\
\hline Session Jam & 05 & 25 & 04 & 25 & 09 & 25 \\
\hline $\begin{array}{l}\text { Students } \\
\text { Politics }\end{array}$ & 08 & 40 & 06 & 37.5 & 14 & 38.888 \\
\hline $\begin{array}{l}\text { Teachers } \\
\text { Politics }\end{array}$ & 05 & 25 & 04 & 25 & 09 & 25 \\
\hline $\begin{array}{l}\text { Political } \\
\text { Instability }\end{array}$ & 02 & 10 & 02 & 12.5 & 04 & 11.111 \\
\hline Total & 20 & 100 & 16 & 100 & 36 & 100 \\
\hline
\end{tabular}

The table shows that $40 \%$ teachers of Dhaka University have commented as the prime cause of students Unrest is student politics as against $37.5 \%$ teachers of Rajshahi University respectively. Average $38.888 \%$ teachers both of the Universities considered the student politics as the prime cause of students' unrest under the study

\section{Opinions of the Teachers in Respect of Infrastructural Facilities}

Every teacher was asked 'Yes' 'No' questions in regards of elicit information on infrastructural facilities in both of the Universities. The answers are assessed in the following tables. 
Table: Infrastructural Facilities

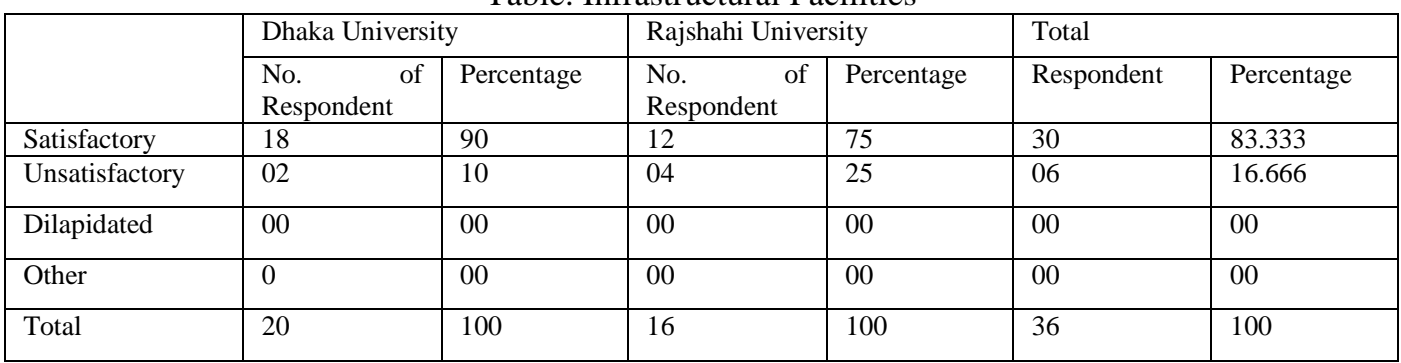

The table shows that $90 \%$ teachers of Dhaka University answered 'Yes' to the satisfactory level as against $75 \%$ of the Rajshahi University under the study. Average $83.333 \%$ told that the infrastructures are satisfactory.

\section{Opinions of the Teachers on Session Jam}

Teachers were interviewed to know their opinions on the departmental session jam. The answers are given in the following table.

Table: Opinions of the Teachers on the Departmental Session Jam

\begin{tabular}{|l|l|l|l|l|l|l|}
\hline \multirow{2}{*}{$\begin{array}{l}\text { Type } \\
\text { Question }\end{array}$} & Dhaka University & Rajshahi University & \multicolumn{2}{l|}{ Total } \\
\cline { 2 - 7 } & $\begin{array}{l}\text { No. of } \\
\text { Respondents }\end{array}$ & $\begin{array}{l}\text { Percentage } \\
\%\end{array}$ & $\begin{array}{l}\text { No. } \\
\text { Respondents }\end{array}$ & $\begin{array}{l}\text { Percentage } \\
\%\end{array}$ & $\begin{array}{l}\text { No. } \\
\text { Respondents }\end{array}$ & $\begin{array}{l}\text { Percentage } \\
\%\end{array}$ \\
\hline Yes & 04 & 20 & 05 & 31.25 & 09 & 25 \\
\hline No & 16 & 80 & 11 & 68.75 & 27 & 75 \\
\hline Total & 20 & 100 & 16 & 100 & 36 & 100 \\
\hline
\end{tabular}

The table shows that $80 \%$ respondents of Dhaka University and $68.75 \%$ respondents of Rajshahi University told that there is no session jams in their department whereas only $20 \%$ respondents of Dhaka University and 09\% respondents of Rajshahi University told that there is namely session jot in their department. Average 25\% respondents told the same answer of having departmental session jam whereas $75 \%$ told having no departmental session jam.

\section{Effect on Society}

\section{Effect on student's unrest}

The study has found some social effects created by students' unrest. The following table shows the teachers comments on the respective issue.

Table6: Effects on Society of the Students' Unrest

\begin{tabular}{|c|c|c|c|c|c|c|}
\hline \multirow[t]{2}{*}{ Types of Effect } & \multicolumn{2}{|c|}{ Dhaka University } & \multicolumn{2}{|c|}{ Rajshahi University } & \multicolumn{2}{|l|}{ Total } \\
\hline & $\begin{array}{l}\text { No. of } \\
\text { Respondent }\end{array}$ & Percentage & $\begin{array}{l}\text { No. of } \\
\text { Respondent }\end{array}$ & Percentage & Respondent & Percentage \\
\hline $\begin{array}{l}\text { Creating } \\
\text { social conflict }\end{array}$ & 10 & 50 & 08 & 50 & 18 & 50 \\
\hline $\begin{array}{l}\text { Decreasing } \\
\text { confidence of } \\
\text { people on higher } \\
\text { education }\end{array}$ & 05 & 25 & 04 & 25 & 09 & 25 \\
\hline $\begin{array}{l}\text { Creating } \\
\text { terrorists }\end{array}$ & 03 & 15 & 02 & 12.5 & 05 & 13.888 \\
\hline $\begin{array}{l}\text { Increasing eve } \\
\text { teasing }\end{array}$ & 02 & 10 & 02 & 12.5 & 04 & 11.111 \\
\hline Increasing killing & 00 & 00 & 00 & 00 & 00 & 00 \\
\hline $\begin{array}{l}\text { Increasing } \\
\text { hijacker }\end{array}$ & 20 & 100 & 16 & 100 & 36 & 100 \\
\hline
\end{tabular}

The table shows that $50 \%$ teachers of Dhaka and Rajshahi University answered that there is a negative effects of students' unrest on the society. Average 50\% teachers told the same reply. They also accused of other parameters like; decreasing confidence of people on higher education, creating terrorists and increasing eve teasing created by students' unrest.

\section{Economic Effects}

The comments of the teachers in the context of economic effect of students' unrest has been shown in the following table 
Table6: Economic Effects of Students' Unrest

\begin{tabular}{|l|l|l|l|l|l|l|}
\hline \multirow{2}{*}{ Types of Effect } & \multicolumn{2}{|l|}{ Dhaka University } & \multicolumn{2}{l|}{ Rajshahi University } & \multicolumn{2}{l|}{ Total } \\
\cline { 2 - 7 } & $\begin{array}{l}\text { No. of } \\
\text { Respondent }\end{array}$ & Percentage & $\begin{array}{l}\text { No. of } \\
\text { Respondent }\end{array}$ & Percentage & Respondent & Percentage \\
\hline $\begin{array}{l}\text { Economic Slow } \\
\text { down }\end{array}$ & 12 & 60 & 10 & 62.5 & 22 & 61.111 \\
\hline $\begin{array}{l}\text { Shortage of Budget } \\
\text { of university }\end{array}$ & 04 & 20 & 03 & 18.75 & 07 & 19.444 \\
\hline $\begin{array}{l}\text { Extended } \\
\text { educational } \\
\text { expenses }\end{array}$ & 00 & 00 & 02 & 12.5 & 02 & 5.555 \\
\hline $\begin{array}{l}\text { Loss of national } \\
\text { resources }\end{array}$ & 04 & 20 & 01 & 06.25 & 05 & 31.25 \\
\hline Others & 00 & 00 & 00 & & 00 & \\
\hline Total & 228 & 100 & 156 & 100 & 384 & 100 \\
\hline
\end{tabular}

The table shows that $60 \%$ teachers of Dhaka University and $62.5 \%$ teachers Rajshahi University answered that there is a negative effects of students' unrest on the economy. Average $61.111 \%$ teachers told the same reply. They also accused of other parameters like; shortage of Budget of university, extended educational expenses and loss of national resources created by students' unrest.

\section{Opinions of the Teachers on the Effects of Students' Unrest in Higher Education}

Opinions of the teachers on the effects of students' unrest in various aspects has been shown in the following table

Table: Effects on Higher Education Level

\begin{tabular}{|l|l|l|l|l|l|l|}
\hline \multirow{2}{*}{} & \multicolumn{2}{|l|}{ Dhaka University } & \multicolumn{2}{l|}{ Rajshahi University } & Total \\
\cline { 2 - 7 } & $\begin{array}{l}\text { No. } \\
\text { Respondent of }\end{array}$ & Percentage & $\begin{array}{l}\text { No. } \\
\text { Respondent }\end{array}$ & Percentage & Respondent & Percentage \\
\hline $\begin{array}{l}\text { Losing the } \\
\text { standard of } \\
\text { higher education }\end{array}$ & 12 & 60 & 10 & 62.5 & 22 & 61.111 \\
\hline $\begin{array}{l}\text { Creating session } \\
\text { jam }\end{array}$ & 05 & 25 & 04 & 25 & 09 & 25 \\
\hline $\begin{array}{l}\text { Wasting valuable } \\
\text { time }\end{array}$ & 03 & 15 & 02 & 12.5 & 05 & 13.888 \\
\hline Total & 20 & 100 & 16 & 100 & 36 & 100 \\
\hline
\end{tabular}

The table shows that $60 \%$ respondents of Dhaka University and $62.5 \%$ respondents of Rajshahi University have implicated the loss of standard of higher education is the main effect of students' unrest. It has also effect on session jot and wasting valuable time. Average $61.111 \%$ respondents held up the loss of standard of higher education created by students' unrest under the study.

\section{Effects on Higher Educational Institution}

The effect on higher education has been shown in the following table.

Table: Effects on Higher Educational Institutions

\begin{tabular}{|c|c|c|c|c|c|c|}
\hline \multirow[t]{2}{*}{ Types of Effect } & \multicolumn{2}{|l|}{ Dhaka University } & \multicolumn{2}{|c|}{ Rajshahi University } & \multicolumn{2}{|l|}{ Total } \\
\hline & $\begin{array}{l}\text { No. of } \\
\text { Respondent }\end{array}$ & Percentage & $\begin{array}{l}\text { No. of } \\
\text { Respondent }\end{array}$ & Percentage & Respondent & Percentage \\
\hline $\begin{array}{l}\text { Losing the } \\
\text { Teacher- } \\
\text { Student } \\
\text { relationship }\end{array}$ & 08 & 40 & 04 & 25 & 12 & 33.34 \\
\hline $\begin{array}{l}\text { Creating } \\
\text { session jam }\end{array}$ & 10 & 50 & 6 & 37.5 & 16 & 44.44 \\
\hline $\begin{array}{l}\text { Shortage of } \\
\text { budget of the } \\
\text { University }\end{array}$ & 00 & 00 & 02 & 12.5 & 02 & 05.55 \\
\hline $\begin{array}{l}\text { Undo the } \\
\text { reputation of } \\
\text { the institution }\end{array}$ & 00 & 00 & 02 & 12.5 & 02 & 05.55 \\
\hline $\begin{array}{lr}\text { Undo } & \text { the } \\
\text { standard } & \text { of } \\
\text { education } & \end{array}$ & 02 & 10 & 02 & 12.5 & 04 & 11.12 \\
\hline Total & 20 & 100 & 16 & 100 & 36 & 100 \\
\hline
\end{tabular}


The table shows that $50 \%$ teachers of Dhaka University and $37.5 \%$ teachers of Rajshahi University have implicated the creating session jam as the major effect of students' unrest on educational institutions. Average $44.44 \%$ teachers held up the creating session jam as the major effect on higher educational institutions created by students' unrest under the study.

\section{Recommendations for Teachers}

\section{Recommendations}

- Teachers need to put in more time monitoring their students' performance, with regular use of 'tests' and assignments. They should also strive to foster their students 'humanity'. They should also act as the 'mentor' of their students.

- They should not involve their students' in political interest

- They should remember that they are the maker of nation. So, to make an educated and prosperous nation, they avoid all corruptions and perform their duties sincerely.

- Teachers should be punctual in their duties and at the same time they should arrange oriental meeting, seminar or such they need to make aware of their students about study and about the future plan of life.

\section{Recommendations for students}

- Students should be attentive to their study so that they can reach in their targeted goal.

- They should not involve them in politics before completing their formal education.

- They may be involving them in some social activities with their good companions and at the same time they should avoid bad companions.

- They should now and then try to join cultural activities which may give them refreshment to their monotony.

- Students should always be competitive to achieve good result. So, they should be punctual in library working regularly.

\section{Recommendations for students' guardians}

- Guardians should be alert to their sons/daughters what they are doing in the hall or mess. How they spend their money and whether they sometimes do otherwise activities.

- Sometimes they can check the study curricular. They also can take a test on various courses. Guardians should always be attentive to their sons/daughters outlook, mode of work and attitude and daily moving tendency.

- Guardians should take an account they provide money for their sons/daughters. They should make aware their sons/daughters about the hardship and future plan of life now and then

\section{Recommendations for Higher Education Institutions}

- Higher education institutions need to ensure sufficient educational facilities. They should establish a number of different clubs for science, arts, social science, debate, sport and culture. Every student should be a member of at least one club in accordance with his/her particular interest. These clubs should be led jointly by teachers and students. The leading positions in these clubs would be occupied by competent and interested people on a roster basis. There would be no permanent leader positions in the clubs.

- Higher education institutions need to introduce not only examination to judge students' academic performance, but also competitive occasions to judge their performance in terms of social activities i.e. sports, music, debate and general knowledge. These measures would be foster social identity in students and as a result, they would not turn to politics to find a social identity.

- Higher education institutions need to introduce knock-out rules so that students who were not sincere, committed or able would not be permitted to stay in higher education institutions without achieving satisfactory progress.

\section{Recommendations for Government}

Following recommendations have been made for our government

- Government should sanction sufficient funds for building required halls in the higher level of educational institutions.

- Govt. should provide sufficient transport facilities for higher education institutions.

- Govt. should take necessary steps to stop teachers and students politics.

\section{Conclusion}

The final comment is that to address the existing problems, Bangladesh urgently needs a united strong political commitment; otherwise there is no hope of achieving an appropriate higher education atmosphere. We have to remember that the students who died as a result of the fighting caused by students' unrest or politics are our own sons/daughters or brothers/sisters. And they are our asset. Therefore, every professional member of 
society should be committed to help building the best prospects for our students. Moreover, everybody needs to bear in mind that self-development cannot be authentic development until Bangladesh is no longer a developing, but a developed country. Furthermore, a situation of unrest knows no laws, so students' unrest is a treat to anybody's life, even that of the political leaders or their children. Especially, students' unrest in higher education has a dangerous effect on society and life. So, it needs to explore its remedy. The researcher tried to recommend to the fact. It may be hoped that by enforcing the recommendations, students' unrest may be removed from the higher educational institutions and higher education environment would be achieved.

\section{References}

[1]. Brass, Paul R. 2003. The Production of Hindu-Muslim Violence in Contemporary India. Oxford University Press, New Delhi. P-5.

[2]. Karim, S.A. 2005. Sheikh Mujibur: Triumph and Tragedy. The University Press Limited, Dhaka. P-9.

[3]. Monem, Mobasser. 2007. 'Crisis of Democracy: The Nexus between Money, Crime and politics in Bangladesh'. Paper for Regional Networking - a Chance for Science and Scholarship' Colloquium for Humboldt Fellows and Awardees in Thailand. P-18.

[4]. Parry, Jonathan. 2000. "The crisis of corruption" and the "idea of India": a worm's eye view. In Pardo, Italo ed. The Morals of Legitimacy: Between Agency and System. Berghahn Books, Oxford. P-21.

[5]. Rahman, A.T. Rafiqur. 2006. Bangladesh in the Mirror: An Outsider Perceptive on a Struggling Democracy. The University Press Limited, Dhaka. P-12.

[6]. Wilkinson, Steven I. 2005. Votes and Violence: Electoral Competition and Communal Riots in India. Cambridge University Press, Delhi. P-27.

[7]. Daily Star 2007 'Judicial Probe into DU Violence' 16 November

[8]. 8. Bangladesh University Grants Commission (2006), Strategic Plan for Higher Education n Bangladesh: 2006-2026, Dhaka.

[9]. Bangladesh University Grants Commission (2005), Annual Report-2005

[10]. Bangladesh University Grants Commission (2004), Amui Repott-2004

[11]. Donald Ekong, '1 from the UNESCO Regional Coosultation on Higher Education- A Concept Paper, 2003.

[12]. Hafiz GA Siddiqi (2005), "Quality Assurance in Conventional Private Universities of Bangladesh: Problems and Prospects", Social Science Review, Dhaka.P-21.

[13]. Mahfuzul Huq (2003), "Financing Higher Education in the Public Universities of Bangladesh:

[14]. The Present Scenario, a paper present at a seminar in septembcr'2003 in Dhaka organized by the Bangladesh University Grants Commission.

[15]. Ministry of Education, Government of Bangladesh, National Education Policy-2000.

[16]. Monjur Morshed Mahmud (2002), "Quality Assurance in Public Universities of Bangladesh-An Overview” A paper presented in a seminar on" Quality Assurance in Higher Education in Bangladesh" organized by UGC and held in Dbaka in July 2002 ,

[17]. Islam, Taherul. (2002). An Analysis of Public Recurring Expenditure of Higher Education in Bangladesh. (A Mimeograph), Bangladesh University Grants Commission. 